\title{
Development and application of watershed-scale indicator to quantify non-point source P losses in semi-humid and semi-arid watershed, China
}

\author{
Jingjun $\mathrm{Su}^{\mathrm{a}}$, Xinzhong $\mathrm{Du}^{\mathrm{a}}$, Xuyong $\mathrm{Li}^{\mathrm{a}, *}$, Xiaoxue Wang ${ }^{\mathrm{a}}$, Wenzan $\mathrm{Li}^{\mathrm{a}}$, \\ Wangshou Zhang ${ }^{\mathrm{a}}$, Huiliang Wang ${ }^{\mathrm{a}}$, Zhen $\mathrm{Wu}^{\mathrm{b}}$, Baolin Zheng ${ }^{\mathrm{c}}$ \\ a State Key Laboratory of Urban and Regional Ecology, Research Center for Eco-Environmental Sciences, Chinese Academy of Sciences, \\ No. 18 Shuangqing Road, Haidian District, Beijing 100085, China \\ ${ }^{\mathrm{b}}$ Environmental Protection Center, Ministry of Transport, No. 10 Hepingli Eastern Street, Beijing 100013, China \\ ' Soil Fertilization Institute, Chengde, Hebei, China
}

\section{A R T I C L E I N F O}

\section{Article history:}

Received 28 January 2015

Received in revised form

30 November 2015

Accepted 3 December 2015

Available online 6 January 2016

\section{Keywords:}

Non-point source

Phosphorus indicator

Inverse distance weights

Semi-humid and semi-arid watershed

\begin{abstract}
A B S T R A C T
Quantifying non-point source (NPS) phosphorus (P) pollution loads is essential for watershed nutrients management. This study intended to develop a NPS P indicator which (1) was suitable in semi-humid and semi-arid watersheds of Northern China; (2) integrated the key NPS P loss factors and constructed them in a simple and physically understandable way and (3) kept P loss forms distinctively separate. An inverse distance-based delivery ratio was proposed to count for the P delivery efficiency from source to watercourses. We applied this P indicator in Luan River Watershed (LRW) of northern China under typical hydrological years and seasons. Results demonstrated that this NPS P indicator predicted reasonable NPS TP loads using simple methods and readily obtainable inputs. The sub-watersheds located in the south of LRW were recognized as the high risk areas of NPS P loss to Panjiakou reservoir. The upland and paddy fields near the river channels were particularly posing high risk and thus should be treated with prioritized management practices such as soil conservation and recommended fertilization. Rainfallrunoff related variables rather than P source variables explained more of the spatial variation in NPS P load and percentages. Using this tool could give policy makers insight into the component and location of NPS P pollution that needs to be the focus of policy at watershed scales before sophisticated studies were conducted in smaller scales.
\end{abstract}

(c) 2015 Elsevier Ltd. All rights reserved.

\section{Introduction}

Phosphorus $(\mathrm{P})$ is widely regarded as a limiting nutrient for primary production in aquatic systems, and in excess it may impair water quality by accelerating the production of algae and aquatic plants (Correll, 1998). Reducing nutrient inputs into water bodies is considered as the most effective strategy for controlling water pollution and sustaining high ecological status (Conley et al., 2009). Owing to the effective control of point sources in the past decades, non-point sources (NPS) particularly agricultural activities have become the leading contributor to water quality degradation worldwide. In 2010, a national pollution census first indicated that in China the agriculture's contribution to total P loads in receiving

\footnotetext{
* Corresponding author. Tel.: +86 1062849428 ; fax: +86 1062849428. E-mail address: xyli@rcees.ac.cn (X. Li).
}

waters was up to $67.4 \%$ (Zhang, 2010a), which has raised extensive interests on NPS pollution from both government and scientists.

Quantifying loads of NPS pollution and its components is essential for watershed or regional nutrient management planning. Approaches including export coefficient models (ECM) (Ding et al., 2010; Johnes, 1996) and mechanistic models (e.g., SWAT, HSPF) (Mishra et al., 2007; Shen et al., 2014) have been applied world widely in NPS pollutant load estimation. The ECM has the advantage of requiring less data and has fewer parameters, but doesn't consider the influence of spatial heterogeneity of rainfall and underlying surfaces (Ding et al., 2010). The mechanistic models can provide accurate results, but often encounter difficulties in application because of their complicated structures and strict requirements for the input data (Zhang, 2010b). This phenomenon was particularly prominent in countries without long term and spatially dense monitoring data and basic or empirical field studies, such as China (Ongley et al., 2010; Shen et al., 2012). 
The Chinese researchers have developed several local NPS P quantification methodologies (Chen et al., 2008, 2010; Han et al., 2011; Yang et al., 2012). Chen et al. (2008, 2010) proposed a model framework to analyze the biogeochemical P flows in agroecosystem on the basis of emission inventory and full $\mathrm{P}$ balance calculation. The P inputs included P brought by mineral fertilizer, livestock manure, other organic fertilizers, precipitation, seeding and irrigation, and the outputs included plant uptake, runoff and leaching. Han et al. (2011) introduced a concept of net anthropogenic phosphorus accumulation and calculated it in Beijing by deriving data from fertilizer use, human food and animal feed, nonfood $\mathrm{P}$ and riverine P. Yang et al. (2012) estimated the potential P loads from cropping, animal production and rural living in a typical county of Northern China Plain. These methodologies were mostly established on a P-balance basis and the outputs were generally indicative of the potential losable P in source. Whereas the NPS P loss potential was not determined by source potential alone, but also by transport potential (Gburek et al., 2000). Few of these studies took consideration of the role of P transport factors (e.g., runoff, field to stream distances) in determining P delivery routes and efficiency, except for Yang et al. (2012) who used scenarios of delivery coefficients to count the likely $P$ delivery ratios from source areas to watercourses. In addition, the terrain $P$ enters watercourses as dissolved $\mathrm{P}(\mathrm{DP})$ carried by surface and subsurface runoff and particulate P(PP) associated with eroded soils (Sharpley et al., 2003). They vary greatly in their relevance to aquatic eutrophication because DP is readily bio-available and PP potentially bio-available (Boström et al., 1988). Separating TP loads into these forms and pathways would allow a detailed examination of the P load composition and of the factors influencing both the relative and absolute magnitude of these $\mathrm{P}$ components.

The main objective of this work was to develop an indicator to quantify the NPS P losses by integrating a range of contributory factors determining NPS P loss from terrain to water within a single calculation system. Our target is an estimator which follows the principle that the coincidence of high source potential and high transport potential determined the actual high NPS pollution risk; keeps P transport forms (e.g., DP and PP) and processes (e.g., surface runoff, subsurface runoff and soil erosion) distinctly separate; and is structured in a way that the individual parameters of calculation have physical meaning. A second objective of this study was to apply NPS P indicator in a semi-humid and semi-arid watershed of China and characterize the variations in NPS P predictions in response to hydrological condition changes in order to obtain important insights into P management in watershed scale.

\section{Methods and methodology}

\subsection{Site description}

Luan River watershed (LRW) is a sub-basin of Hai River Basin (HRB) in Northern China. The Luan River originates near the border between Hebei Province and Inner Mongolia, flowing through plateau, mountain and plain from west to east. This study mainly investigated the mountainous part of LRW located at the upstream of an important Panjiakou Reservoir (Fig. 1).

Due to the data availability, nine sub-watersheds with hydrometric stations installed in the outlets were applied with LRW NPS P indicator (LRW-PI). These sub-watersheds were drained by Budeng river, Yixun river and Yimatu river in the north, by Wulie river, Laoniu river and Xingzhou river in the middle and by Pu river, Liu river and Sa river in the south (Fig. 1). Sub-watershed boundaries were delineated by ArcSWAT tool in ArcGIS 9.3 software (ESRI, Inc., Redlands, CA) based on a digital elevation model (DEM) expressed as a $90 \mathrm{~m}$ raster and the geographic coordinates of hydrometric stations.

The LRW is characterized by a semi-humid and semi-arid monsoon climate and an annual average rainfall of $520 \mathrm{~mm}$. Influenced by the topography, rainfall decreases from the south to the north. More than half of the annual rainfall occurred between June and September. Percentages of different soil types or land uses in each
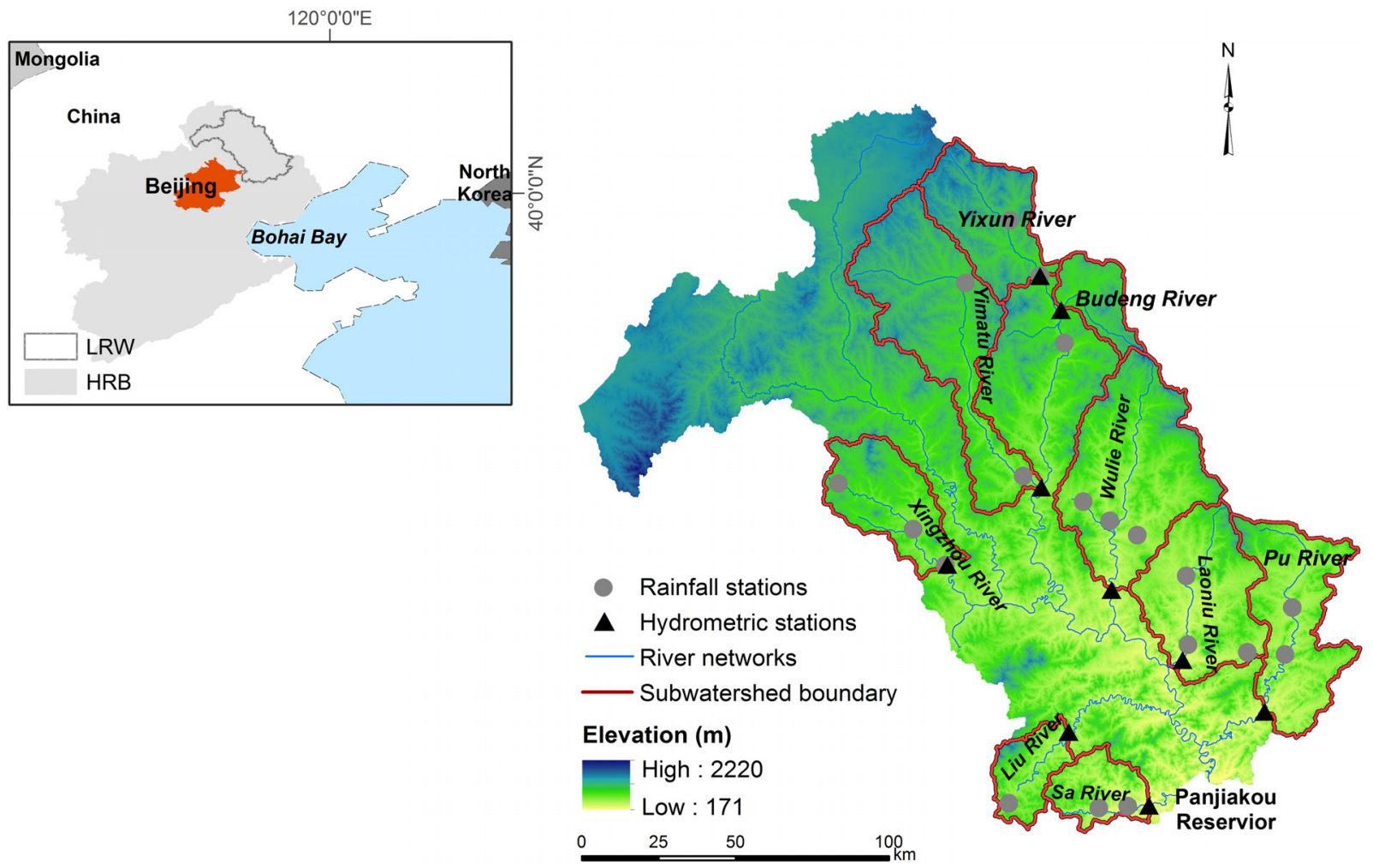

Fig. 1. Locations of Luan River Watershed and the studied sub-watersheds. 
Table 1

Characteristics of selected sub-watersheds in LRW.

\begin{tabular}{|c|c|c|c|c|c|c|c|c|c|}
\hline & Yixun & Budeng & Yimatu & Xingzhou & Wulie & Laoniu & $\mathrm{Pu}$ & Liu & Sa \\
\hline Area $\left(\mathrm{km}^{2}\right)$ & 1259 & 519 & 2421 & 1107 & 2416 & 1682 & 1632 & 560 & 598 \\
\hline Elevation $(\mathrm{m})^{\mathrm{a}}$ & 1271 & 1071 & 1107 & 890 & 788 & 624 & 645 & 755 & 582 \\
\hline Slopes (degree) ${ }^{\mathrm{a}}$ & 12.2 & 11.4 & 11.9 & 11.6 & 12.4 & 12.0 & 11.6 & 15.0 & 16.7 \\
\hline \multicolumn{10}{|c|}{ Percentage of soils (\%) } \\
\hline Fluvo-aquic & 2.3 & 5.0 & 4.0 & 7.8 & 5.3 & 8.5 & 6.2 & 3.6 & 2.0 \\
\hline Regosols & 1.9 & 6.1 & 3.5 & 0.8 & 5.0 & 10.1 & 10.1 & 2.2 & 9.0 \\
\hline Cinnamon soil & 6.6 & 19.4 & 19.9 & 37.5 & 41.2 & 51.9 & 53.1 & 42.3 & 47.6 \\
\hline Brown soil & 79.1 & 65.1 & 67.5 & 53.1 & 47.9 & 28.8 & 28.6 & 45.8 & 37.2 \\
\hline \multicolumn{10}{|c|}{ Percentage of landuse (\%) } \\
\hline Grass land & 19.0 & 24.7 & 19.0 & 16.3 & 22.8 & 36.4 & 32.7 & 30.2 & 21.6 \\
\hline Forest & 56.2 & 34.8 & 52.6 & 57.4 & 53.9 & 42.1 & 42.4 & 49.6 & 65.6 \\
\hline Dry land & 21.1 & 35.0 & 24.3 & 22.9 & 20.5 & 20.2 & 21.9 & 15.7 & 11.3 \\
\hline Paddy land & 0.0 & 0.1 & 0.3 & 1.1 & 0.8 & 0.1 & 0.1 & 0.0 & 0.0 \\
\hline \multicolumn{10}{|c|}{ Soil Particle size $(\%)^{b}$} \\
\hline Clay & 23.7 & 20.9 & 22.2 & 20.2 & 19.2 & 17.4 & 15.8 & 16.8 & 16.8 \\
\hline Sand & 41.9 & 47.2 & 44.0 & 47.6 & 50.3 & 53.9 & 56.7 & 54.2 & 54.3 \\
\hline Silt & 34.4 & 31.9 & 33.8 & 32.2 & 30.6 & 28.7 & 27.6 & 29.1 & 28.9 \\
\hline Soil depth (m) & 82.9 & 88.4 & 85.6 & 92.4 & 94.0 & 97.5 & 98.5 & 89.4 & 94.0 \\
\hline Soil OM (\%) & 7.5 & 5.5 & 6.5 & 5.0 & 4.6 & 3.4 & 2.6 & 3.9 & 3.9 \\
\hline \multicolumn{10}{|l|}{$\mathrm{P}$ input $\left(\mathrm{kg} \mathrm{ha}^{-1}\right)^{\mathrm{c}}$} \\
\hline $\mathrm{P}_{\text {fecal }}$ & 24.7 & 24.7 & 25.2 & 25.0 & 28.3 & 31.2 & 29.4 & 46.7 & 52.7 \\
\hline $\mathrm{P}_{\text {urine }}$ & 2.9 & 2.9 & 2.9 & 2.7 & 2.9 & 3.0 & 3.5 & 5.9 & 6.7 \\
\hline $\mathrm{P}_{f e r}$ & 47.9 & 47.8 & 36.2 & 27.7 & 19.4 & 21.2 & 36.1 & 80.8 & 93.1 \\
\hline $\mathrm{P}_{\text {total }}$ & 75.5 & 75.4 & 64.3 & 55.5 & 50.6 & 55.4 & 69.1 & 133.5 & 152.4 \\
\hline
\end{tabular}

a Data were derived from DEM in a resolution of $90 \mathrm{~m} \times 90 \mathrm{~m}$.

b Data were derived from soil P map produced based on 2005 soil survey.

c Data were presented as the P inputs per crop land area (dry land and paddy land).

sub-watershed were derived from the land use and soil maps. The dominant soil types are brown or cinnamon soil depending on sub-watersheds, and the topsoil texture is mainly loamy sandy according to particle size compositions (Table 1). Forest covers the largest area (34.8-65.6\%) in all sub-watersheds, followed by grass land and dry land, and paddy land covers the least (Table 1). Dry lands and paddy lands are generally fragmented and located in hillsides, terraces and flood plains along the river channel and the regular upland crops are corn and vegetables.

The excessive application of mineral fertilizers has long been recognized as an important contributor to NPS nutrient pollution in Chinese agricultural lands. Recently livestock production and rural living have been identified as another one (Du et al., 2014; Yang et al., 2012). In LRW, livestock (mainly pigs, poultry, cattle and sheep) either graze in grassland or are raised in individual farms or centralized feedlots. The latter accounts for the majority of the total stock, being from 85 to $100 \%$ depending on counties and animal types. The waste produced by rural living and livestock production are either treated in limited numbers of disposal facilities, used for biogas producing, or applied to cropland as fertilizers, leaving the rest being washed into watercourses by storm runoff or stablecleaning water (Zhu, 2011). This P indicator only took the waste applied to land into consideration as a source of NPS pollution.

\subsection{Development of $L R W-P I$}

Non-point source $P$ loss is a function of source factors (e.g., soil P status, fertilizer and manure application) and transport factors (e.g., erosion, surface and subsurface runoff, connectivity between the land and the waterbody) (Drewry et al., 2011). Processes determining NPS P loss forms and magnitudes included in this methodology are P solubilization and PP transfer. PP transfers were closely associated with erosion of soil particles or manure dry matter; while DP transfers represented the solubilization of DP from soils, fertilizers and manure and their mobilization driven by surface and subsurface runoff. These processes were used to estimate NPS P loads mobilized in and ready to leave each calculation cell, which represented the potential losable $P$ from terrain sources. A parameter reflecting the degree of hydrological connectivity between source cells and surface waters were further multiplied to obtain the final delivered PP and DP loads. The total NPS P loads entering watercourses were quantified as the sum of delivered PP and DP. Tables 2 and 3 respectively listed the components and equations for LRW-PI computation and Table 4 listed the data sources. All inputs and outputs were eventually expressed as $90 \mathrm{~m}$ raster files and the raster calculations were performed by raster calculator in ArcGIS 9.3 software.

\subsubsection{Particulate P loads leaving the cell}

Particulate P leaving the cells included $\mathrm{P}$ associated with eroded sediments and manure solids mobilized from the source to the cell edge. We quantified the PP loss from soil $\left(\mathrm{PP}_{\text {soi }}, \mathrm{kg} \mathrm{ha}^{-1}\right)$ by multiplying eroded sediment rates $\left(A\right.$, ton ha $\left.{ }^{-1}\right)$ calculated by revised universal soil loss equation (RUSLE) (Renard et al., 1997; Wischmeier and Smith, 1978), topsoil TP concentrations $\left(\mathrm{TP}_{\text {soi }}\right.$, $\mathrm{mg} \mathrm{kg}^{-1}$ ) (Vadas et al., 2009) and P enrichment ratio (ER, unitless) (Sharpley et al., 2002; Vadas et al., 2009) (Eq. (1) in Table 3). The RUSLE inputs include rainfall erosivity (R), soil erodibility (K), slope $(\mathrm{S})$, slope length (L), crop cover-management factor (C) and support practices factor $(\mathrm{P})$ which were respectively derived from long term daily rainfall data, soil maps with the attributes of particle sizes and organic matter, digital elevation model, land cover and management practices (Eq. (4) in Table 3). Considering the local applicability, this study adopted a daily rainfall erosivity model developed for the mountainous area in Beijing (Bi et al., 2006) to estimate the rainfall erosivity factor. The soil erodibility factor K followed the method proposed by Williams et al. (1983) in EPIC model in view of data availability. The length and slope factor (LS) was calculated by the equations from Liu et al. (1994) and McCool et al. (1987). The cover-management factor $C$ and support practice factor $P$ adopted values from previous studies in the similar region of China (Bi et al., 2006; Men et al., 2007). Since eroded sediments were enriched with P compared to source surface soil due to the preferential transport of finer, more sorptive soil and organic 
Table 2

Components of LRW-PI computation.

\begin{tabular}{|c|c|c|}
\hline Components & Determination method & Data required \\
\hline \multicolumn{3}{|l|}{ Particulate P leaving cells } \\
\hline Sediment loss rates & Revised Universal Soil Loss Equation & $\begin{array}{l}\text { DEM, rainfall, land use, soil map, management } \\
\text { practices }\end{array}$ \\
\hline Sediment P concentration & $\begin{array}{l}\text { Empirical equations to determine sediment } \mathrm{P} \\
\text { concentration from soil total } \mathrm{P} \text { and using routine } \\
\text { soil test information to estimate soil total } \mathrm{P}\end{array}$ & $\begin{array}{l}\text { Soil OlsenP and organic matter, enrichment ratio } \\
\text { calculated based on sediment loss rates }\end{array}$ \\
\hline Particulate P loads contributed from soils & & Sediment P concentrations; sediment loss rates \\
\hline Particulate P loads contributed from manure & $\begin{array}{l}\text { Empirical coefficients to estimate PP loads from } \\
\text { manure }\end{array}$ & \\
\hline \multicolumn{3}{|l|}{ Dissolved P leaving cells } \\
\hline $\begin{array}{l}\text { Depths for surface runoff, subsurface runoff and total } \\
\text { runoff }\end{array}$ & Base flow separation & Measured daily flow volumes, sub-watershed area \\
\hline Total runoff depth rank & Classification according to frequency distribution & Total runoff depths \\
\hline $\begin{array}{l}\text { Distribution ratios of surface runoff or subsurface runoff } \\
\text { in total runoff }\end{array}$ & & $\begin{array}{l}\text { Depths for surface runoff, subsurface runoff and } \\
\text { total runoff }\end{array}$ \\
\hline Dissolved P concentration contributed from soil & $\begin{array}{l}\text { Empirical coefficients to estimate dissolved P } \\
\text { concentration in both surface and subsurface } \\
\text { runoff from topsoil test P }\end{array}$ & Soil Olsen P, empirical coefficients \\
\hline Dissolved P loads contributed from manure/fertilizer & $\begin{array}{l}\text { Estimation using census data, empirical } \\
\text { coefficients and runoff data }\end{array}$ & $\begin{array}{l}\text { P fertilization rates, livestock numbers and rural } \\
\text { population, P excretion coefficients, manure } \\
\text { land-applied rates, P utilization rates, total flow } \\
\text { ranks, distribution ratios of runoff/P concentration }\end{array}$ \\
\hline \multicolumn{3}{|l|}{ Cell to water delivery } \\
\hline Distance to streams & Inverse distance weights & River networks \\
\hline
\end{tabular}

particles, ER was used for estimating TP in eroded sediments (Eq. (3) in Table 3). Topsoil TP concentrations were not readily available and were calculated based on soil organic matter and OlsenP concentrations using Eq. (2) in Table 3.

The PP loss contributed by manure application was also considered presuming that part of the applied fecal $P$ was in particulate form. A regional survey in LRW suggested that around 23\% of the urine and $40 \%$ of feces excreted by rural dwellers and livestock were applied to crop lands (Bai, 2010). The manure PP leaving the cell ( $\mathrm{PP}_{\text {man }}, \mathrm{kg} \mathrm{ha}^{-1}$ ) was estimated by summing the land-applied PP in each county according to census data and empirical coefficients cited from worldwide studies, and then dividing by the cropland areas in each county (Eqs. (5) and (6) in Table 3; Table 5). Other land uses were considered to be without manure and fertilizer $\mathrm{P}$ inputs.

\subsubsection{Dissolved P loads leaving the cell}

Dissolved P leaving the cell comprised the soluble parts of soil $\mathrm{P}$, fertilizer $\mathrm{P}$ and manure $\mathrm{P}$ which were available for delivery from source area to cell edges by surface and subsurface runoff. DP contributed by soils was expressed as the DP mass extracted from soil by runoff, and that from manure and fertilizer were obtained by apportioning the total losable DP from manure or fertilizer to surface and subsurface pathways according to distribution ratios of runoff and $\mathrm{P}$ concentration between two pathways. Since runoff parameters were involved in the computation, they were introduced prior to load estimation.

2.2.2.1. Runoff analysis. Runoff analyses were performed on the daily flow records during the 1995-2008 period in studied subwatersheds (Tables 2 and 4). A digital filter technique was first applied to separate the surface and subsurface runoff from the total flow (Nathan and McMahon, 1990). Volumes of the total, surface and subsurface flows were then aggregated and divided by the sub-watershed area to obtain runoff depths (referred as $\mathrm{RD}_{t f}$, $\mathrm{RD}_{\text {sur }}$ and $\mathrm{RD}_{\text {sub }}$ ). Ratios of surface or subsurface runoff depths in total runoff depths were also calculated to reflect the runoff distribution between surface and subsurface pathways $\left(\mathrm{DR}_{\text {sur }}, \mathrm{DR}_{\text {sub }}\right)$. $\mathrm{RD}_{\text {sub }}$ and $\mathrm{RD}_{\text {sur }}$ would be used for the estimation of DP loss contributed by soils, and $\mathrm{RD}_{t f}$, $\mathrm{DR}_{\text {sur }}$ and $\mathrm{DR}_{\text {sub }}$ for the estimation of
DP loss by manure and mineral fertilizer. The $\mathrm{RD}_{t f}$ values were not directly used for the computation but were converted into a unitless parameter named total flow ranks $\left(\mathrm{TF}_{\text {rank }}\right)$. The $\mathrm{TF}_{\text {rank }}$ were assigned with a series of values ranging from 0 to 1 and were determined according to the distribution of the annual or seasonal $\mathrm{RD}_{t f}$ in all sub-watersheds during 1995 and 2008. The $\mathrm{RD}_{t f}$ values at quantiles of $5 \%, 15 \%, 30 \%, 45 \%, 60 \%$ and $75 \%$ were set as the boundaries to divide $\mathrm{RD}_{t f}$ into 7 classes. Mean values of the maximum and minimum quantiles in each distance class were then assigned as the $\mathrm{TF}_{\text {rank. }}$ value of each runoff class, which were respectively $0.025,0.1,0.225,0.375,0.525,0.675$ and 0.875 . This parameter reflected the relative magnitudes of a certain $\mathrm{RD}_{t f}$ among studied sub-watersheds in a certain time period, allowing the comparisons of DP losses across sites and time.

2.2.2.1.1. Soil DP mobilized within each cell. Soil DP mobilized within each cell $\left(\mathrm{DP}_{\text {soi }}\right.$, sur, $\mathrm{DP}_{\text {soi }}$, sub, $\left.\mathrm{kg} \mathrm{ha}^{-1}\right)$ was estimated by multiplying runoff depths in each pathway and runoff DP concentrations released by soils (Eqs. (7) and (8) in Table 3). We used a constant coefficient of 0.004 , as many other studies did (Sharpley et al., 2002; Vadas et al., 2009), to convert soil extractable $\mathrm{P}$ concentrations $\left(\mathrm{OlsenP}_{\text {soi }}, \mathrm{mg} \mathrm{kg}^{-1}\right.$ ) to runoff DP concentrations ( $\left.\mathrm{mg} \mathrm{L}^{-1}\right)$. Another coefficient, $\mathrm{DR}_{p c}$, was used to describe P concentration ratio between subsurface and surface pathways. This study assigned a constant value of 1 , assuming no difference between $\mathrm{P}$ concentrations in two pathways.

2.2.2.1.2. Fertilizer DP mobilized within each cell. China consumed high amount of fertilizers but has a relatively low utilization efficiency, being 10-20\% for P (Chen et al., 2008). We estimated the losable fertilizer DP loads in the cropland of each county and then allocated them to different runoff pathways (Eqs. (9) and (10) in Table 3). $\mathrm{P}_{\text {fer }}$ represented the amount of mineral fertilizer P applied to the unit cropland area. It was calculated in county level using census records and cropland area (upland and paddy land). The calculation of mobilized fertilizer DP presumed: (1) all fertilizer P was in soluble form; (2) methods and timing of $\mathrm{P}$ application were uniform in all sub-watersheds; ( 3 ) only $25 \%$ of the applied fertilizer $P$ could be taken up by crops or retained by soils annually and the rest $75 \%$ would be ready for release and (4) $60 \%$ of the fertilizer $P$ was applied during the flood season which covered part of the crop season and $40 \%$ during the non-flood season. We further used the 
Table 3

Equations for LRW-PI computation.

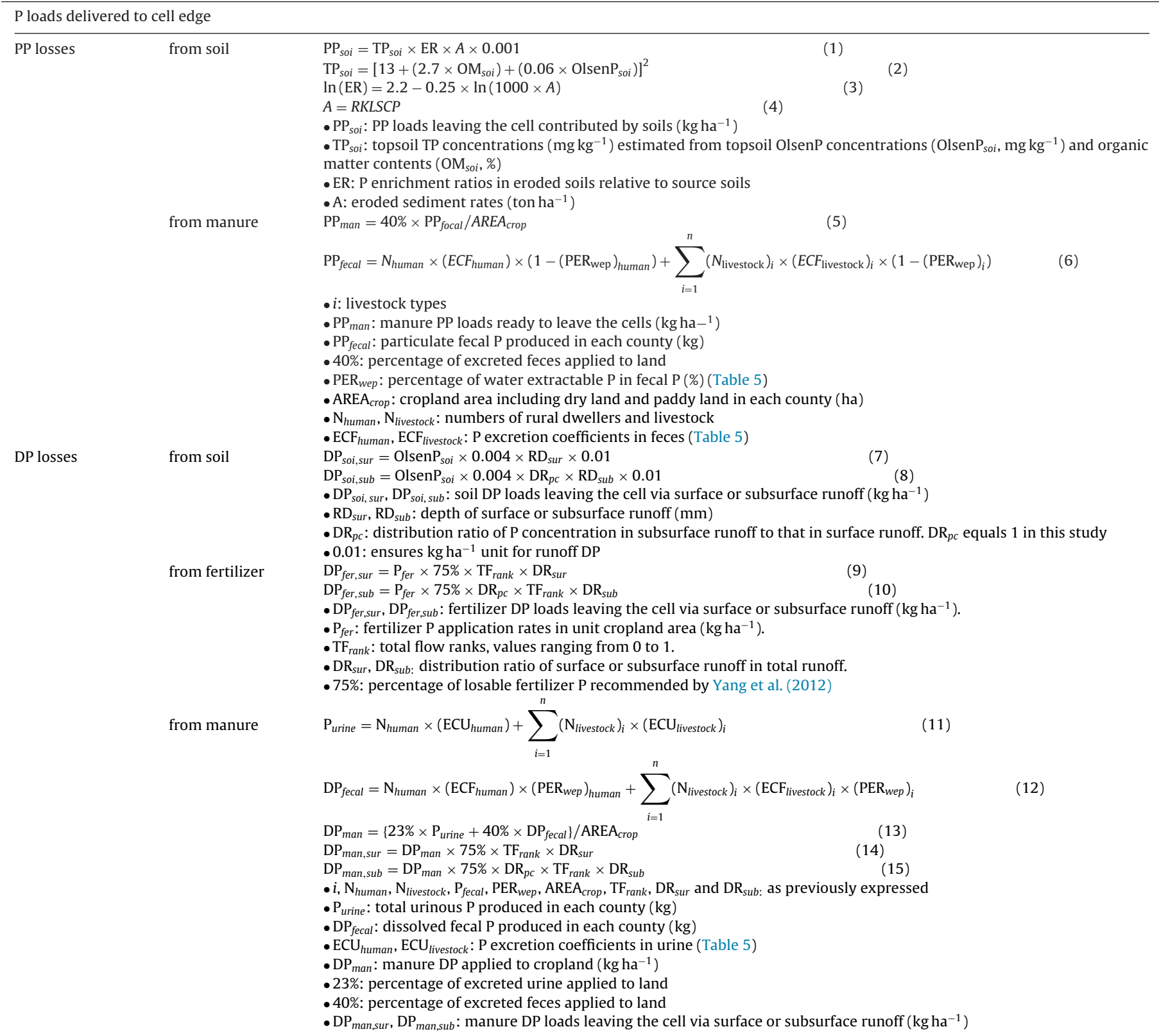

P loads delivered from cell edge to watercourses

\begin{tabular}{|c|c|c|c|}
\hline Cell edge to water delivery & $\begin{array}{l}D=100 /\left(d_{\max }\right)_{i} \\
\bullet\left(d_{\max }\right)_{i}: \text { the highest distance in distance class } i . \\
\bullet 100: \text { a constant to constrain the order of magnitudes. }\end{array}$ & (16) & \\
\hline P loads & $\begin{array}{l}\mathrm{TPP}=\left(\mathrm{PP}_{\text {soi }}+\mathrm{PP}_{\text {man }}\right) \times D \\
\mathrm{TDP}_{\text {sur }}=\left(\mathrm{DP}_{\text {soi,sur }}+\mathrm{DP}_{\text {fer, sur }}+\mathrm{DP}_{\text {man }, \text { sur }}\right) \times D \\
\mathrm{TDP}_{\text {sub }}=\left(\mathrm{DP}_{\text {soi,sub }}+\mathrm{DP}_{\text {fer,sub }}+\mathrm{DP}_{\text {man }, \text { sub }}\right) \times D \\
\mathrm{TDP}=\mathrm{TDP} \mathrm{P}_{\text {sur }}+\mathrm{TDP} \text { sub } \\
\mathrm{TP}=\mathrm{TPP}+\mathrm{TDP} \\
\bullet \mathrm{TPP}, \mathrm{TDP}: \text { total delivered PP or DP loads from each cell } \\
\bullet \mathrm{TDP} \text { sur }, \mathrm{TDP}_{\text {sub }}: \text { total delivered DP loads through surfac } \\
\bullet \mathrm{TP}: \text { total delivered P loads from each cell }\left(\mathrm{kg} \mathrm{ha}^{-1}\right)\end{array}$ & $\begin{array}{l}(17) \\
(21) \\
\text { arface runoff }\end{array}$ & $\begin{array}{l}(18) \\
(19) \\
\text { om each cell }\left(\mathrm{kg} \mathrm{ha}^{-1}\right) \text {. }\end{array}$ \\
\hline
\end{tabular}

products of $\mathrm{DR}_{p c}, \mathrm{TF}_{\text {rank }}$ and runoff distribution ratio per pathway to apportion the losable fertilizer DP into surface and subsurface pathways.

2.2.2.1.3. Manure DP mobilized within each cell. Manure DP was assumed to consist of urinous $\mathrm{P}$ and the water-soluble part of fecal $\mathrm{P}$. The excreted urine $\mathrm{P}\left(\mathrm{P}_{\text {urine }}, \mathrm{kg}\right)$ and dissolved fecal $\mathrm{P}\left(\mathrm{DP}_{\text {fecal }}, \mathrm{kg}\right)$ were estimated based on census data regarding rural population and livestock production and empirical excretion coefficients (Eqs (11) and (12) in Table 3). As stated previously, only $23 \%$ of the urine and $40 \%$ of the excreted feces were applied to crop lands. This calculation also presumed that $75 \%$ of the applied DP man was considered to be losable to watercourses after crop uptake and soil retention. The losable manure DP was distributed into each pathway as did for fertilizer DP (Eqs. (14) and (15) in Table 3). 
Table 4

Types, sources and description of the data used in the case study.

\begin{tabular}{|c|c|c|}
\hline Data type & Data source & Data description \\
\hline DEM & $\begin{array}{l}\text { International scientific data service platform, Chinese Academy of } \\
\text { Science }\end{array}$ & A grid size of $90 \mathrm{~m} \times 90 \mathrm{~m}$ \\
\hline Soil P & Soil and fertilizer institute of Chengde city, Hebei province & Soil Olsen $\mathrm{P}$ in $90 \mathrm{~m} \times 90 \mathrm{~m}$ grid \\
\hline Soil properties & National second soil survey & Soil texture, organic matter $(1: 250,000)$ \\
\hline Land Use & Data sharing infrastructure of earth system science, China & Land uses classification $(1: 100,000)$ \\
\hline Runoff & $\begin{array}{l}\text { Chengde branch of Hebei provincial bureau of hydrology and water } \\
\text { resources survey }\end{array}$ & Daily runoff from 9 hydrometric stations (1995-2008) \\
\hline Rainfall & $\begin{array}{l}\text { Chengde branch of Hebei provincial bureau of hydrology and water } \\
\text { resources survey }\end{array}$ & Daily rainfall from 19 rainfall stations (1995-2008) \\
\hline P inputs & Annual census published by each county's statistical bureau & Fertilizer application, rural population, livestock production (2005) \\
\hline
\end{tabular}

Table 5

P excretion coefficients cited from multiple literature sources.

\begin{tabular}{|c|c|c|c|}
\hline Categories & 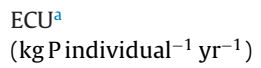 & $\begin{array}{l}\mathrm{ECF}^{\mathrm{a}} \\
\left(\mathrm{kg} \mathrm{P}^{\text {Pindividual }}{ }^{-1} \mathrm{yr}^{-1}\right)\end{array}$ & $\mathrm{PER}_{w e p}$ \\
\hline Cattle/horses & 1.1 & 6.46 & $30 \%$ \\
\hline Hogs & 0.79 & 4.36 & $50 \%$ \\
\hline Sheep & 0.38 & 1.88 & $60 \%$ \\
\hline Poultry & 0 & 0.25 & $25 \%$ \\
\hline Human & 0.21 & 0.31 & $30 \%$ \\
\hline
\end{tabular}

a P excretion coefficients in urine and feces (Gao, 2002; NEPD, 2002).

b Percentage of water soluble P in excreted fecal P (Ajiboye et al., 2004; Hainze et al., 2004; Kleinman et al., 2005; Turner and Leytem, 2004).

\subsubsection{Cell to water delivery}

Particulate and dissolved P loads mobilized in each cell as calculated above were further weighed by the proximity of cells to stream channel to obtain the delivered P loads (Tables 2 and 3). Many phosphorus indexes considered the distance from source to watercourses as an effective proxy for runoff risk (Buczko and Kuchenbuch, 2007; Drewry et al., 2011). They assumed that the closer to streams or rivers, the higher potential to be delivered to watercourses. Distances to watercourses were divided into groups and rating values were assigned to each distance group to reflect the potential of $P$ delivery. For example, rating values were 1 and 0.2 , respectively for distance groups $\leq 50 \mathrm{~m}$ and $>50 \mathrm{~m}$ in field study (Bechmann et al., 2009) and 1, 0.9, 0.8, 0.6 and 0.3, respectively for distances $\leq 500 \mathrm{~m}, 500-1500 \mathrm{~m}, 1500-3000 \mathrm{~m}, 3000-5000 \mathrm{~m}$ and $>5000 \mathrm{~m}$ in watershed-scale study (Zhou and Gao, 2011). These values were generally determined based on experiences or expert judgements. The LRW-PI adopted the inverse-distance weight approach, which could mathematically compute the delivery ratios and was proposed by King et al. (2004), to determine the cell-towater delivery ratios of $\mathrm{P}$ at various distances. The linear distances $(d, \mathrm{~m})$ between the center of each cell and rivers were calculated by Euclidean distance tool in ArcGIS 9.3 software based on the river networks. Then the distances were divided into unequal interval distance classes: 0-250 m, 251-500 m, 501-1000 m, 1001-2000 m, 2001-5000 $\mathrm{m}, 5001-10,000 \mathrm{~m}$ and $10,000-20,000 \mathrm{~m}$ and the maximum distance in each distance class $\left(d_{\max }\right)$ were used to calculate the inverse distance-based delivery ratio $(D)$ following Eq. (16). The constant 100 was used to constrain the order of results magnitudes. The total delivered PP, DP and TP loads were finally calculated following Eqs. (17)-(21).

\subsection{Application of LRW-PI in typical hydrological conditions}

Five typical hydrological conditions including annual average (AA), average flood season (AFS), average non-flood season (ANFS), wet year (WY) and dry year (DY) were selected to characterize the variations in NPS P predictions in response to hydrological condition changes. Based on the analysis over the 14-year rainfall records in the sub-watersheds (see Appendix 1), the year 1995 and year
2000 respectively presented relatively higher rainfall amount and relatively lower rainfall amount than any other years and therefore were chose to respectively represent the WY and DY. Considering that more than $75 \%$ of the annual rainfall occurred from June to September, this study defined the period from June to September as the flood season and the rest of the year including January to May and October to December as the non-flood season. LRW-PI was applied in studied sub-watersheds on ArcGIS platform. The output NPS TP, TDP sur, $\mathrm{TDP}_{\text {sub }}$, TDP and TPP in years or seasons were finally expressed as $90 \mathrm{~m} \times 90 \mathrm{~m}$ raster layers and the mean values in each sub-watershed were derived. Cross-site relationships between NPS $P$ loads or percentages and selected input variables were examined to explore which factors were influencing the spatial variation in NPS P predictions. All statistical analysis including Pearson correlations, Mann-Whitney U test were carried out by R software (R Core Team, 2012).

\section{Results and discussions}

\subsection{Observations of $P$ inputs, soil $P$ status, rainfall and runoff}

Fig. 2a showed clear spatial variation in P inputs and soil P status. Budeng sub-watershed received the highest average $P$ inputs per hectare of sub-watershed area due to owning the highest percentage (35\%) of area covered by dry land (Fig. 2a; Table 1). Liu and Sa sub-watersheds ranked the second and Laoniu and Wulie subwatersheds received the lowest $P$ inputs. Mineral fertilizer, rather than manure, was the major source of $P$ inputs (38-63\%). Topsoils in all sub-watersheds except Xingzhou were enriched with OlsenP $\left(\geq 20 \mathrm{mg} \mathrm{kg}^{-1}\right.$ ), indicating a higher potential to lose more $P$, either in dissolved form or sediment-associated form, into runoff.

Fig. 2b displayed that the annual average rainfall and runoff depths tended to decrease from the south to the north. The significantly higher rainfall and runoff depths in the southern sub-watersheds (e.g., Sa, Liu and $\mathrm{Pu}$ ) than in the northern subwatersheds (e.g., Budeng, Yimatu and Yixun) suggested a much higher P transport potential in the southern sub-watersheds. $\mathrm{DR}_{\text {sub }}$ ranged from $46 \%$ to $95 \%$, highlightening the dominance of subsurface pathway in runoff transfer. This might also suggest a high possibility for the occurrence of nutrients transfer via subsurface pathway, reaching groundwater or returning to streams as lateral flow or springs. We found that $\mathrm{DR}_{\text {sub }}$ had a close relationship with cinnamon soil percentages $\left(R^{2}=0.45, p=0.046\right)$ which were strongly correlated with soil sand proportions $\left(R^{2}=0.88, p<0.001\right)$. The sandy texture of soils might have favored water infiltration.

\subsection{Annual average total loads}

As LRW-P indicator estimated, the 14-year annual average total NPS P loads in studied sub-watersheds ranged from 0.49 to $1.22 \mathrm{~kg} \mathrm{ha}^{-1}$ and averaged at $0.79 \mathrm{~kg} \mathrm{ha}^{-1}$ (Fig. 2c). These values 

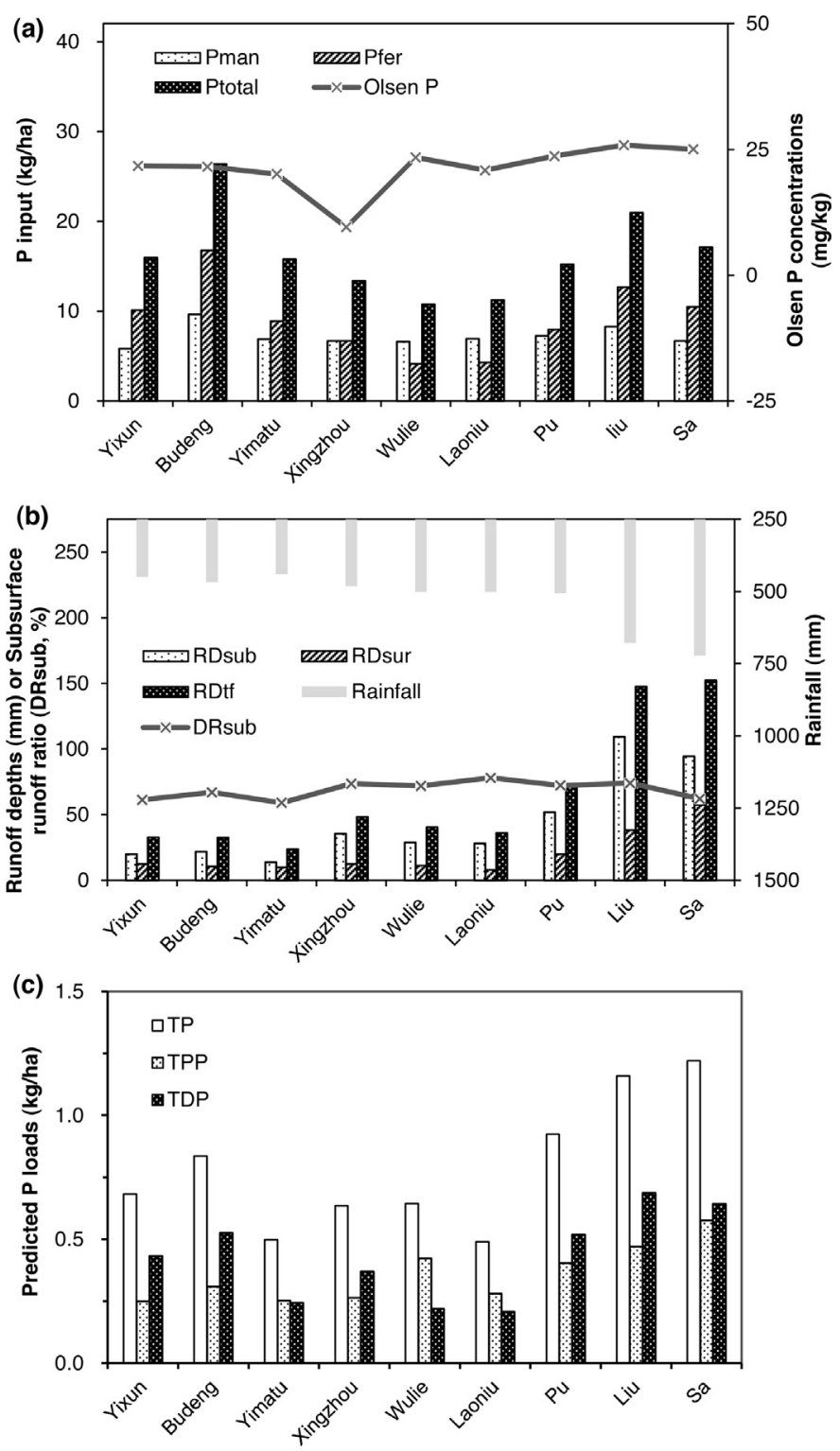

Fig. 2. (a) The annual average $P$ inputs per hectare of sub-watershed area and the average topsoil OlsenP concentrations, (b) the annual average runoff depths and subsurface runoff percentage and (c) the NPS P loadsin each sub-watershed. From the left to the right of the $\mathrm{x}$-axis, sub-watersheds were arranged in the order from the north to the south geographically.

felt within or closely to previously reported TP loads from predominantly agricultural basins in Europe $\left(<0.1-6 \mathrm{~kg} \mathrm{ha}^{-1}\right.$ ) (Kronvang et al., 2007; Withers and Jarvie, 2008), United States (median value of $2.25 \mathrm{~kg} \mathrm{ha}^{-1}$ ) (Beaulac and Reckhow, 1982) and northern China plain (0.8-1.6 $\mathrm{kg} \mathrm{ha}^{-1}$ at delivery ratios of 5\% and 10\%) (Yang et al., 2012). The average annual NPS TP loads showed clear spatial variation (Fig. 2c), with the southern sub-watersheds (e.g., Sa, Liu and $\mathrm{Pu}$ ) having apparently higher values than those in other sub-watersheds. This was expected since $\mathrm{Sa}$, Liu, Pu subwatersheds were characterized by high rainfall and runoff, relatively high $P$ inputs and soil OlsenP contents and steeper slopes (Fig. 2a and b; Table 1). As one of the northern sub-watersheds with less rainfall and runoff, Budeng sub-watershed presented unexpected higher TP loads than its adjacent Yixun and Yimatu subwatersheds (Fig. 2c). This might be mainly attributed to the highest $P$ inputs per unit of watershed area and the highest percentage of dry land (Fig. 2a; Table 1).

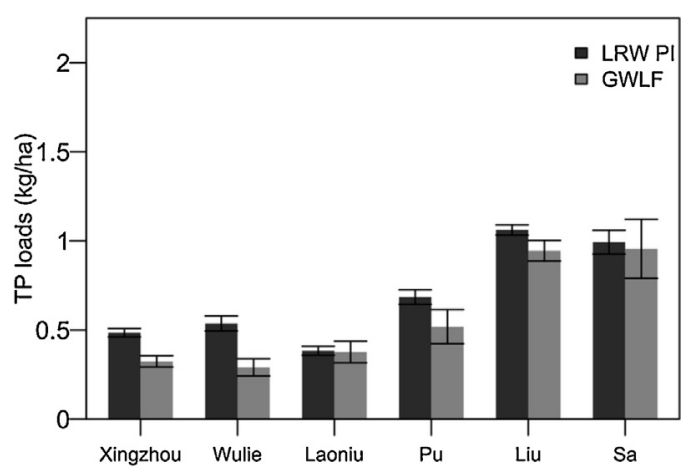

Fig. 3. The comparison of average annual NPS TP loads in Xingzhou, Wulie, Laoniu, $\mathrm{Pu}$, Liu and Sa sub-watersheds during the period 2000-2008 simulated by LRW-PI and GWLF. Error bars represented the standard deviation among 9 years.

We also compared the annual NPS P loads in six sub-watersheds during the period 2000-2008 simulated by LRW-P indicator and generalized watershed loading function (GWLF) model. The accuracy of the GWLF model simulation was overall acceptable and the model calibration and verification details were described in Du et al. (2014) and Du (2014). Fig. 3 showed that despite of the observable differences in Xingzhou, Wulie and Pu sub-watersheds, both approaches captured consistent pattern in the relative magnitudes of NPS TP loads among sub-watersheds (Fig. 3). Mann-Whitney $U$ test indicated no significant difference between the two groups of means $(p=0.24)$.

\subsection{Composition of annual average NPS P loads}

Analysis of the NPS P load composition could highlight P sources and pathways, as well as the potential influence of $P$ on water quality. As LRW P indicator estimated, NPS TP consisted of 35-65\% of PP, $25-45 \%$ of DP in subsurface runoff and $10-25 \%$ of DP in surface runoff (Fig. 4a). TDP exceeded TPP in either loads or percentages in most of the sub-watersheds except Wulie and Laoniu (Fig. 4a). This suggested that majority of the lost NPS P would be readily available for the aquatic organisms in the downstream rivers or reservoir. While there has been a widely-hold assumption that most $P$ loss from agricultural land occurs via surface runoff in association with soil particles (Heathwaite and Dils, 2000). The significant contribution from DP loss in subsurface runoff explained this contrast. No measurements of either P distribution in soil profile or $\mathrm{P}$ concentrations in subsurface flow were made to provide direct evidence of subsurface P loss in studied sub-watersheds. However, a 7-year monitoring of well water in 13 sites of LRW indicated that TP concentrations in well water $\left(0.05-0.93 \mathrm{mg} \mathrm{L}^{-1}\right)$ already reached critical level which may promote surface water eutrophication (0.02 $\mathrm{mg} \mathrm{L}^{-1}$ ) (Correll, 1998). This indirectly evidenced the occurrence of substantial subsurface P loss. We hypothesized three reasons for this significant subsurface DP loss: (1) subsurface flow was the major flow pathway, as previously discussed; (2) the sandy soils generally had lower P adsorption capacity (Buczko and Kuchenbuch, 2007); and (3) the long term application of manure and fertilizer had elevated $P$ saturation degree in subsoils and consequently facilitated the P downward or lateral movement.

Fig. $4 \mathrm{~b}$ revealed that mineral fertilizer and soils were the major sources of NPS TP pollution. Mineral fertilizer was mainly contributing to DP loss while soils to PP loss (Fig. 4b). Unlike the findings of Chen et al. (2010) which identified livestock feeding and rural life as the leading source of agricultural P loads (57\%) in a national scale, our results seemed to underestimate the contribution of livestock production and rural living $(<25 \%)$ to NPS $\mathrm{P}$ pollution. The results differed because we defined that NPS 
(a)

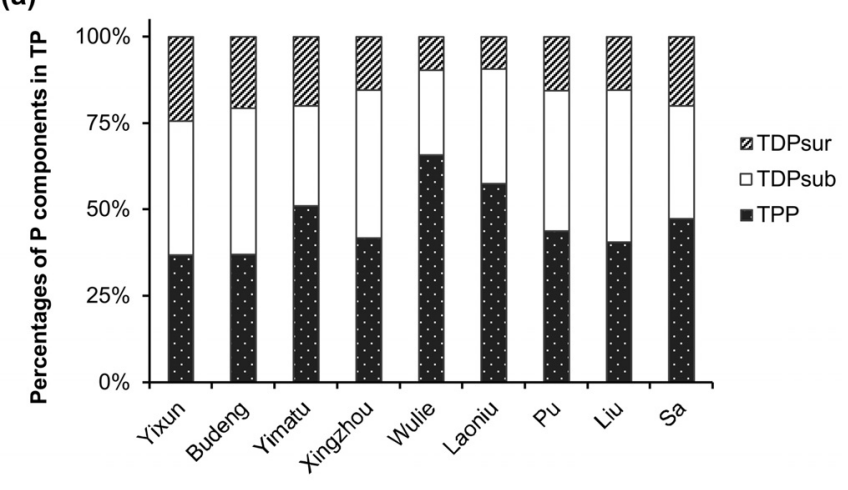

(b)

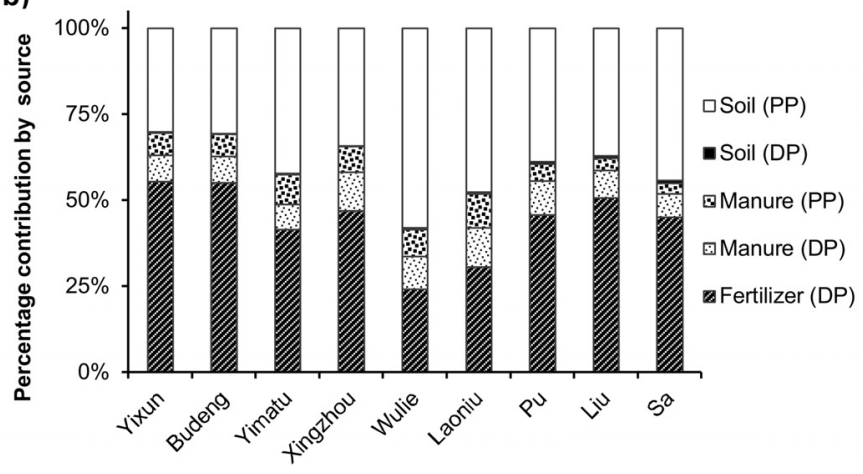

Fig. 4. The relative contribution of different $P$ components (a) and $P$ sources (b) to NPS TP loads in each sub-watershed.

$P$ pollution only count the land-applied part of waste produced by rural living and livestock feeding and treated the rest as point sources. In recent years, the pollution in rural areas of China due to livestock and rural dwellers has raised increasing attention from both governments and scientific communities. However there hasn't been a clear definition of non-point source pollution in these areas up to date. As to the spatial correlation between P inputs and NPS P predictions, only P inputs were positively correlated with TDP and associated TDP/TP percentage (Table 6). No significant correlationships were found between soil OlsenP and any type of predicted

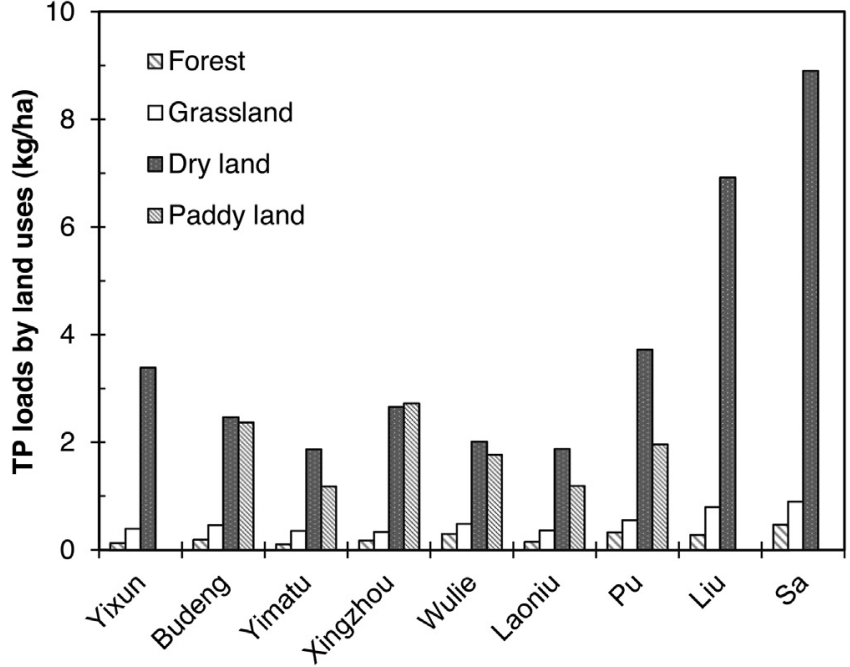

Fig. 5. The annual average NPS TP loads varied with land use types in each subwatershed.

NPS P loads. These might suggest that variations in the P source explained limited spatial variations in NPS P loads among studied sub-watersheds.

\subsection{Annual average NPS P loads influenced by land uses}

Variations in NPS TP loads with land uses reflected the influence of human activities. Dry land had the highest TP loads, ranging from $1.9 \mathrm{~kg} \mathrm{ha}^{-1}$ to $8.9 \mathrm{~kg} \mathrm{ha}^{-1}$. These values felt well within the ranges reported for arable lands in United States and Yongding River basin, China (Fig. 5, Table 7). Paddy land was second to dry land and had TP loads ranging from $1.2 \mathrm{~kg} \mathrm{ha}^{-1}$ to $2.5 \mathrm{~kg} \mathrm{ha}^{-1}$. These two land use types had relatively high TP loads due to the application of manure and mineral fertilizer. The grassland and forest had relatively lower TP loads, which were comparable to previously documented values in American and European countries (Fig. 5, Table 6). Considering that croplands in this study were generally located in sloped uplands and riverside areas as well as the influence of distance on $P$ transfer, the dry and paddy lands near river channels were

Table 6

NPS P loads and percentages displaying significant correlations with selected input variables at critical probability levels of $0.05,0.01$ and 0.001 .

\begin{tabular}{|c|c|c|c|c|c|c|c|c|c|c|c|c|c|c|c|}
\hline \multirow[t]{2}{*}{ Datasets } & \multirow[t]{2}{*}{ Input variables } & \multicolumn{2}{|l|}{$\mathrm{TP}$} & \multicolumn{2}{|l|}{ ТPP } & \multicolumn{2}{|l|}{$\mathrm{TDP}_{\text {sub }}$} & \multicolumn{2}{|l|}{$\mathrm{TDP}_{\text {sur }}$} & \multicolumn{2}{|l|}{ TDP } & \multicolumn{2}{|l|}{ TDP/TP } & \multicolumn{2}{|c|}{$\mathrm{TDP}_{s u b} / \mathrm{TDP}$} \\
\hline & & $r^{\mathrm{a}}$ & $P r^{\mathrm{b}}$ & $r$ & $\operatorname{Pr}$ & $r$ & $\operatorname{Pr}$ & $r$ & $\operatorname{Pr}$ & $r$ & $\operatorname{Pr}$ & $r$ & $\operatorname{Pr}$ & $r$ & $\operatorname{Pr}$ \\
\hline \multirow[t]{11}{*}{ AA dataset } & $\mathrm{P}_{\text {total }}$ & 0.51 & ns & 0.12 & ns & 0.64 & ns & 0.66 & ns & 0.68 & $0.043^{*}$ & 0.69 & $0.04^{*}$ & -0.28 & ns \\
\hline & OlsenP & 0.54 & ns & 0.63 & ns & 0.37 & ns & 0.42 & ns & 0.4 & ns & -0.13 & ns & -0.15 & ns \\
\hline & Grass land \% & 0.14 & ns & 0.2 & ns & 0.21 & ns & -0.17 & ns & 0.08 & ns & -0.19 & ns & 0.64 & ns \\
\hline & Forest $\%$ & 0.2 & ns & 0.34 & ns & -0.02 & ns & 0.27 & ns & 0.08 & ns & -0.11 & ns & -0.4 & ns \\
\hline & Dry land \%c & 0.46 & ns & -0.65 & ns & -0.25 & ns & -0.25 & ns & -0.26 & ns & 0.25 & ns & -0.05 & ns \\
\hline & Dry land \% & -0.83 & $0.01^{*}$ & -0.86 & $0.006^{* *}$ & -0.64 & ns & -0.72 & $0.04^{*}$ & -0.7 & ns & 0.39 & ns & 0.05 & ns \\
\hline & $\mathrm{RD}_{\text {sub }}$ & 0.89 & $0.002^{* *}$ & 0.84 & $0.004^{* *}$ & 0.82 & $0.007^{* *}$ & 0.62 & ns & 0.79 & $0.012^{*}$ & 0.17 & ns & 0.17 & ns \\
\hline & $\mathrm{RD}_{\text {sur }}$ & 0.9 & $0.001^{* *}$ & 0.88 & $0.002^{* *}$ & 0.71 & $0.033^{*}$ & 0.78 & $0.013^{*}$ & 0.77 & $0.016^{*}$ & 0.18 & ns & -0.18 & ns \\
\hline & $\mathrm{RD}_{t f}$ & 0.91 & $<0.001^{* * *}$ & 0.87 & $0.002^{* *}$ & 0.8 & $0.01^{*}$ & 0.68 & $0.04^{*}$ & 0.8 & 0.01 & -0.26 & ns & 0.06 & ns \\
\hline & $\mathrm{DR}_{\text {sub }}$ & -0.07 & ns & 0.03 & ns & 0.07 & ns & -0.5 & ns & -0.12 & ns & 0.03 & ns & 1 & $<0.001^{* * *}$ \\
\hline & Rainfall & 0.86 & $0.003^{* *}$ & 0.9 & $0.001^{* *}$ & 0.7 & $0.037^{*}$ & 0.62 & ns & 0.7 & $0.034^{*}$ & 0.04 & ns & 0.08 & ns \\
\hline \multirow[t]{5}{*}{ Full dataset ${ }^{\mathrm{e}}$} & $\mathrm{RD}_{\text {sub }}$ & 0.83 & $<0.001^{* * *}$ & 0.79 & $<0.001^{* * *}$ & 0.72 & $<0.001^{* * *}$ & 0.75 & $<0.001^{* * *}$ & 0.79 & $<0.001^{* * *}$ & 0.23 & ns & 0.16 & ns \\
\hline & $\mathrm{RD}_{\text {sur }}$ & 0.80 & $<0.001^{* * *}$ & 0.80 & $<0.001^{* * *}$ & 0.61 & $<0.001^{* * *}$ & 0.79 & $<0.001^{* * *}$ & 0.70 & $<0.001^{* * *}$ & 0.16 & ns & -0.32 & ns \\
\hline & $\mathrm{RD}_{t f}$ & 0.83 & $<0.001^{* * *}$ & 0.80 & $<0.001^{* * *}$ & 0.69 & $<0.001^{* * *}$ & 0.78 & $<0.001^{* * *}$ & 0.75 & $<0.001^{* * *}$ & 0.21 & ns & -0.23 & ns \\
\hline & $\mathrm{DR}_{\text {sub }}$ & -0.31 & ns & -0.34 & ns & -0.09 & ns & -0.51 & ns & -0.25 & ns & 0.047 & ns & 1 & $<0.001^{* * *}$ \\
\hline & Rainfall & 0.91 & $<0.001^{* * *}$ & 0.94 & $<0.001^{* * *}$ & 0.71 & $<0.001^{* * *}$ & 0.82 & $<0.001^{* * *}$ & 0.78 & $<0.001^{* * *}$ & 0.06 & ns & -0.45 & ns \\
\hline
\end{tabular}

a Pearson $r$, not squared.

b “*”, “**”, “***” respectively represent significance at critical probability levels of 0.05, 0.01 and 0.001 . "ns”, not significant.

c Spatial correlation between dry land \% and NPS P loads including Budeng sub-watershed.

d Spatial correlation between dry land \% and NPS P loads excluding Budeng sub-watershed.

e Full dataset includes data in five hydrological conditions (AA, WY, DY, AFS, ANFS). 
extremely susceptible to runoff $P$ loss and thus required special attention and prioritized management practices.

The percentage of crop land in a watershed has been considered as an important explanatory variable for nutrient loss concentrations or loads. Taranu and Gregory-Eaves (2008) found a significant and positive cross-study correlationship between Agricultural land $\%$ and lake TP loads at a broad spatial scale $(r=0.53$, one tailed $p=0.021$ ). However no such significant correlations were found in our study (Table 6). We found that Budeng sub-watershed was an outliner and excluding it significantly improved the correlation significance particularly between dry land\% and TP, TPP or TDP sur. Yet the negative correlation coefficients suggested that the correaltionship was contrary to what was previously reported. This contrast, as well as the limited correlations between $P$ inputs and P loads, might indicate that the impacts of P source on the spatial variation in NPS $P$ load prediction had been overwhelmed by those of other factors such as rainfall and runoff. Morse and Wollheim (2014) reported that the inter-annual climate and associated runoff variability had masked the influences of land use changes on nutrient fluxes in a suburbanizing watershed. While the exception of Budeng subwatershed did evidence the determining effect of $P$ source factors (high dry land \% and P inputs) on TP loss loads.
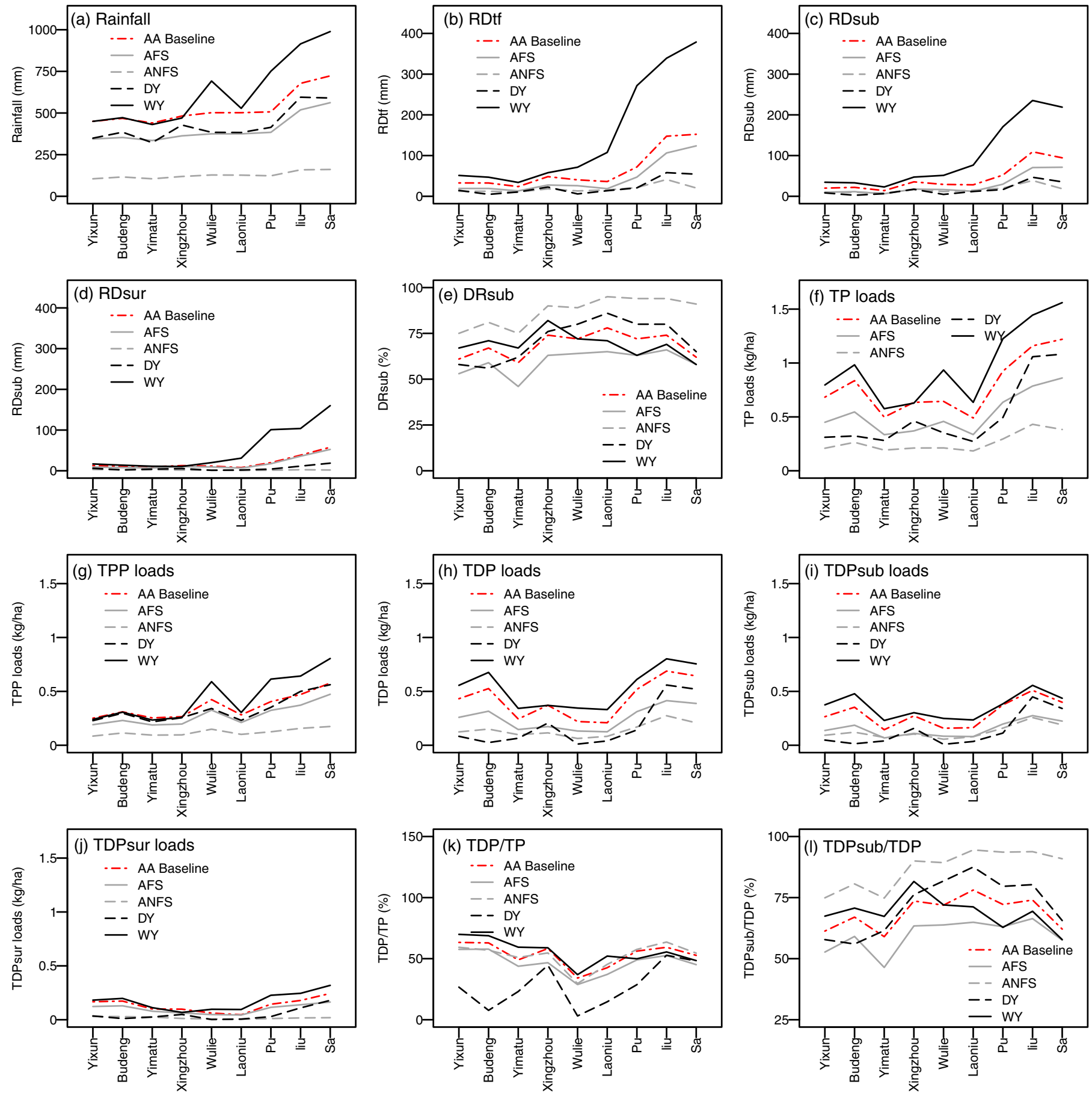

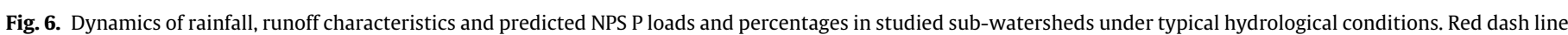
represented the AA baseline. (For interpretation of the references to color in this figure legend, the reader is referred to the web version of this article.) 
Table 7

Variation in P loads by land uses cited from literature sources.

\begin{tabular}{lllcl}
\hline Land use type & Country/location & \multicolumn{3}{l}{ P loads $\left(\mathrm{kg} \mathrm{ha}^{-1}\right)^{\mathrm{a}}$} \\
\cline { 3 - 5 } & & Min & Max & Mean \\
\hline \multirow{2}{*}{ Arable land } & UK & 0.7 & 0.8 & 0.7 \\
& USA & 0.02 & 18.6 & 1.3 \\
& Europe & 0.1 & 6 & - \\
& China-national & 0.9 & 5.3 & 2.3 \\
\multirow{3}{*}{ Grass land } & China-Yongding river basin & - & - & 9 \\
& UK & 0.02 & 0.5 & 0.2 \\
& USA & 0.02 & 4.9 & 0.3 \\
Forest & North America & 0.3 & 2.8 & 0.9 \\
& Australia & 0.002 & 1.9 & 0.3 \\
& USA & 0.1 & 0.4 & 0.25 \\
& Australia & 0.001 & 0.2 & 0.06 \\
\hline
\end{tabular}

a Literature sources: (Beaulac and Reckhow, 1982; Chen et al., 2010; Guo et al., 2014; Kronvang et al., 2007; Young et al., 1996).

\subsection{NPS P predictions varied with hydrological conditions}

Fig. 6 displayed the dynamics of rainfall, runoff and predicted NPS P loads and percentages in WY, DY, AFS and ANFS. As many studies demonstrated (Ahmadi et al., 2014; Du et al., 2014; Jeppesen, 2009), the wet year with high rainfall and runoff increased NPS TP losses by $18-45 \%$ relative to the AA baseline depending on sub-watersheds, and the dry year with low rainfall and runoff reduced NPS TP loads by $10-60 \%$. These TP changes were mainly attributed to runoff DP changes in both transport pathways and eroded PP losses. It is worthy pointing out that we observed unchanged TPP loads in northern sub-watersheds in both WY and DY. How PP losses from soils were calculated was responsible for this. The soil PP loss was the product of $\mathrm{TP}_{\text {soi }}$, erosion rates and $\mathrm{P}$ enrichment ratios (Eq. (1) in Table 3). The erosion rates were positively correlated with rainfall while ER was inversely correlated with erosion rates due to the selective transport of sediment particles (Eqs. (3) and (4) in Table 3). The unchanged rainfall amount in Yixun, Budeng and Yimatu resulted in unchanged TPP predictions. While the counteraction between erosion rates and P enrichment ratio was responsible for the unchanged TPP prediction in DY. Since we didn't consider the runoff effects on PP loss, TPP estimation heavily relied on rainfall $(r=0.94, \operatorname{Pr}<0.001$, Table 6). Therefore the application of LRW-P indicator in sites or years with relatively low runoff/rainfall ratios might overestimate PP loss. Another important implication from what we observed in the DY was that reduced runoff may reduce sediment erosion rates but not necessarily reduce PP loss, and vice versa. Between the hydrological seasons, around $60-70 \%$ of the annual NPS TP, TPP and TDP sur and TDP losses occurred in the flood season (Fig. 6f; Fig. 6g; Fig. 6h; Fig. $6 \mathrm{j}$ ), corresponding to that more than $70 \%$ of the annual runoff occurred in the flood season (Fig. 6b). Yet $\mathrm{TDP}_{\text {sub }}$ loads maintained at comparable levels in flood season and non-flood season (Fig. 6i). This could be explained by the relatively constant subsurface runoff depths in the two seasons (Fig. 6c).

We examined the cross-site correlations between NPS P predictions and rainfall-runoff variables based on either the AA dataset or the full dataset including five hydrological conditions. Rainfall-runoff variables demonstrated the most and the strongest correlationships with NPS P loads or percentages, even though some of them could have been influenced by multi-collinearity among variables (Table 6). By comparing the correlation coefficients and significance, we observed stronger spatial correlationships between NPS P loads or percentages and rainfall and runoff variables than between NPS P loads or percentages and $P$ source variables $\left(P_{\text {total }}\right.$, OlsenP, land use \%). The significant and positive correlationships between NPS P loads and rainfall-runoff variables implied that: (1) sub-watersheds characterized by high

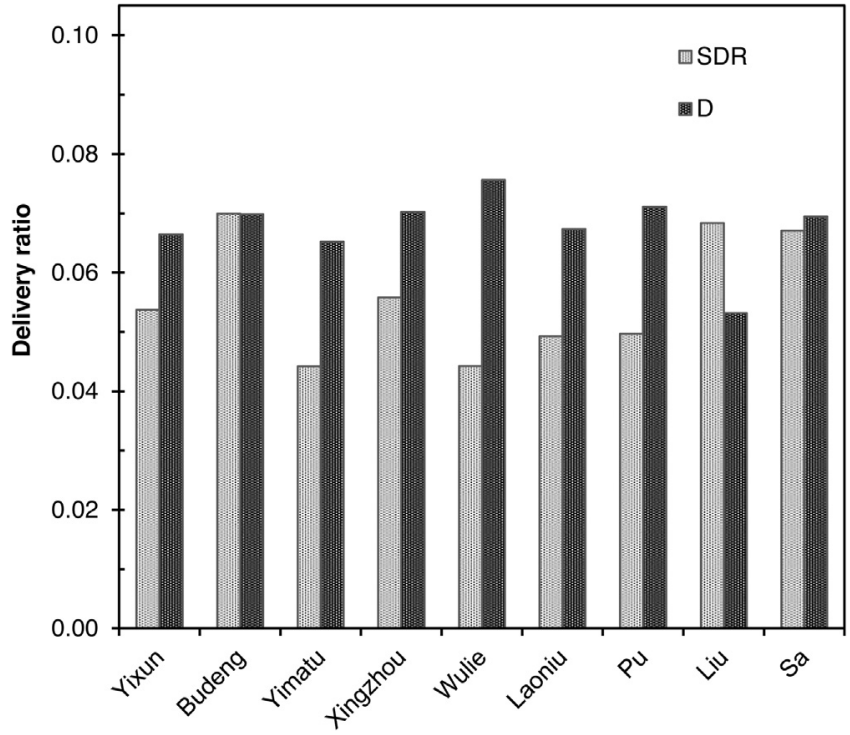

Fig. 7. Comparisons of the average delivery ratios in each sub-watershed estimated by GWLF function and the inverse distance approach.

rainfall, runoff and $\mathrm{P}$ transport potential such as Liu, Sa and $\mathrm{Pu}$ should be listed as high risk areas for NPS P loss; (2) high rainfall or runoff periods (e.g., wet year; flood season) should be the critical time targeting NPS P losses and (3) management practices that reduce runoff depths could lower $P$ losses. Another important finding was that $\mathrm{DR}_{\text {sub }}$ played a minor role in determining NPS P loads, but well determined the percentages of $\mathrm{TDP}_{\text {sub }}$ in TDP (Table 6).

\subsection{Highlights and uncertainties}

The delivery of $P$ from field edge to watercourses was an important process for the modeling approach and in reality was controlled by complex and dynamic interactions between rainfall characteristics and soils and surface properties. It was particularly difficult to quantify since there were few sources of data on which to base the coefficients when developing a simple indicator (Heathwaite et al., 2003). This study treated this processes as a "black box" and used a delivery ratio based on distances. We compared the delivery ratios assessed as the inverse distance weights in LRW-PI and as a function of the watershed area $\left(\mathrm{km}^{2}\right)$ in GWLF model (Eq. (22)) (Haith and Shoenaker, 1987).

$\mathrm{SDR}=0.451 \times\left(\text { Area }_{\text {basin }}\right)^{-0.298}$

Delivery ratios by the two methods generally felt within in a narrow range from 0.04 to 0.08 (Fig. 7). In Budeng and Sa subwatersheds they were perfectly matched. Greater D values than SDR values in sub-watersheds of Laoniu, Pu, Wulie and Yimatu were mainly attributed to that these sub-watersheds had larger areas and SDR values were adversely correlated with areas. Liu sub-watershed had similar area with Sa sub-watershed but lower D values, probably due to sparser river networks in Liu subwatershed. Using the area of entire watershed may underestimate the delivery ratios since only part of the watershed area could contribute to the delivery of nutrients and sediments (Lane et al., 2009). This phenomenon was particularly prominent in regions with low or discontinuous hydrological connectivity due to low rainfall and/or high infiltration. In our study which was located in semi-humid and semi-arid regions and had relatively high infiltration, the inverse distance-based delivery ratio should be more suitable for NPS P loads estimation.

We are also conscious that as a watershed-scale indicator, this methodology unavoidably would encounter uncertainties. The 
coefficients cited from worldwide studies could be one source. For example, this study used a constant coefficient to convert soil Olsen $P$ to runoff $P$ concentrations assuming that soil $P$ extractability was similar among soils. Yet the regression between soil test $\mathrm{P}$ and runoff $P$ could vary with soil types and management (Sharpley et al., 2002). Another coefficient worth mentioning is $\mathrm{DR}_{p c}$. This study assigned a value of 1 , assuming no difference in $P$ concentrations existing between surface and subsurface runoff. Yet this is the ideal situation where there is no $\mathrm{P}$ recession during transport through soil matrix or surface landscape. Many studies reported lower TP or DP in subsurface runoff and the differences varied with studies (Heathwaite et al., 2003; Mittelstet et al., 2011). Therefore the current settings for $\mathrm{DR}_{p c}$ in this methodology might overestimate the contribution from subsurface runoff in soils which were less permeable or had higher $P$ sorption capacity. A slight variation in $\mathrm{DR}_{p c}$ might exert significant influences on the outputs, for example, $\mathrm{P}$ composition. Therefore detailed local studies regarding soil $P$-runoff $P$ relationship and $P$ recession during transport should be conducted in the future to fill this knowledge gap and refine DP loss formulation.

\section{Conclusions}

The LRW-PI was capable to estimate annual and seasonal NPS P loads at sub-watershed scales using simple methods and readily obtainable inputs. The application of LRW-PI in 9 subwatersheds in five hydrological conditions identified the southern sub-watersheds were posing high risk of NPS P loss to water quality in Panjiakou reservoir and the critical timing for NPS P controlling were wet year and flood season. The dry land and paddy fields near the river channels should be treated with prioritized management practices. Considering the significant contribution of subsurface $P$ loss and the difficulty in reducing or controlling subsurface runoff volume, the overall P reduction in studied sub-watersheds should focus on PP loss control and P source control. Conservation practices such as terraced fields, filter strips would greatly intercept the sediment and PP delivery to streams. The recommended fertilization based on soil $P$ test and crop $P$ requirement would effectively reduce DP in both surface and subsurface pathways, as well as PP eroded from soils. The application of an inverse distance-based delivery ratio well reflected the hydrological characteristics in semi-humid and semi-arid regions but greatly reduced the complexity and difficulty to obtain the values. We are conscious that some parts of this P indicator would be improved once local studies fill the knowledge gap. But we strongly recommend using such indicator to help policy makers to screen out high priority areas or time for watershedscale $\mathrm{P}$ management actions before sophisticated research being conducted in smaller scales.

\section{Acknowledgements}

This study was supported by National Natural Science Funding (Grant number: 41401590); The independent project in State Key laboratory of Urban and Regional Ecology, RCEES (Grant number: SKLURE2013-1-05); "One-Three-Five" Project in Chinese Academy of Sciences (Grant number: YSW2013B02-4) and China Postdoc Research Fellowship (Grant number: 2012M510569).

\section{Appendix A. Supplementary data}

Supplementary data associated with this article can be found, in the online version, at http://dx.doi.org/10.1016/j.ecolind.2015. 12.002 .

\section{References}

Ahmadi, M., Records, R., Arabi, M., 2014. Impact of climate change on diffuse pollutant fluxes at the watershed scale. Hydrol. Process. 28, 1962-1972.

Ajiboye, B., Akinremi, O.O., Racz, G.J., 2004. Laboratory characterization of phosphorus in fresh and oven-dried organic amendments. J. Environ. Qual. 33 1062-1069.

Bai, M., (Mater thesis) 2010. Research on the Evaluation of the Pollution from Livestock and Poultry Breeding in Hebei (in Chinese). Agricultural University of Hebei.

Beaulac, M.N., Reckhow, K.H., 1982. An examination of land use-nutrient export relationships. J. Am. Water Resour. Asssoc. 18, 1013-1024.

Bechmann, M., Stålnacke, P., Kværnø, S., Eggestad, H.O., Øygarden, L., 2009. Integrated tool for risk assessment in agricultural management of soil erosion and losses of phosphorus and nitrogen. Sci. Total Environ. 407 749-759.

Bi, X., Duan, S., Li, Y., Liu, B., Fu, S., Ye, Z., Yuan, A., Lu, B., 2006. Study on soil loss equation in Beijing. Sci. Soil Water Conserv. 4, 6-13 (in Chinese).

Boström, B., Persson, G., Broberg, B., 1988. Bioavailability of different phosphorus forms in freshwater systems. Hydrobiologia 170, 133-155.

Buczko, U., Kuchenbuch, R.O., 2007. Phosphorus indices as risk-assessment tools in the USA and Europe-a review. J. Plant Nutr. Soil Sci. 170, 445-460.

Chen, M., Chen, J., Sun, F., 2008. Agricultural phosphorus flow and its environmental impacts in China. Sci. Total Environ. 405, 140-152.

Chen, M., Chen, J., Sun, F., 2010. Estimating nutrient releases from agriculture in China: an extended substance flow analysis framework and a modeling tool. Sci. Total Environ. 408, 5123-5136.

Conley, D.J., Paerl, H.W., Howarth, R.W., Boesch, D.F., Seitzinger, S.P., Havens, K.E. Lancelot, C., Likens, G.E., 2009. Controlling eutrophication: nitrogen and phosphorus. Science 323, 1014-1015.

Correll, D.L., 1998. The role of phosphorus in the eutrophication of receiving waters: a review. J. Environ. Qual. 27, 261-266.

Ding, X., Shen, Z., Hong, Q., Yang, Z., Wu, X., Liu, R., 2010. Development and test of the export coefficient model in the Upper Reach of the Yangtze River. J. Hydrol. $383,233-244$

Drewry, J., Newham, L., Greene, R., 2011. Index models to evaluate the risk of phosphorus and nitrogen loss at catchment scales. J. Environ. Manage. 92, 639-649.

Du, X., (PhD thesis) 2014. The Construction of Watershed Pollution Load Model and Its Application in Luanhe Basin (in Chinese). University of Chinese Academy of Sciences.

Du, X., Li, X., Zhang, W., Wang, H., 2014. Variations in source apportionments of nutrient load among seasons and hydrological years in a semi-arid watershed: GWLF model results. Environ. Sci. Pollut. Res. 21 (10), 6506-6515.

Gao, X., 2002. The Fertilization Handbook, 1st ed. Chinese Agriculture Press, Beijing.

Gburek, W.J., Sharpley, A.N., Heathwaite, L., Folmar, G.J., 2000. Phosphorus management at the watershed scale: a modification of the phosphorus index. J. Environ. Qual. 29, 130-144.

Guo, W., Fu, Y., Ruan, B., Ge, H., Zhao, N., 2014. Agricultural non-point source pollution in the Yongding River Basin. Ecol. Indic. 36, 254-261.

Hainze, M.T.M., Muntifering, R.B., Wood, C.W., McCall, C.A., Wood, B.H., 2004. Faecal phosphorus excretion from horses fed typical diets with and without added phytase. Anim. Feed Sci. Technol. 117, 265-279.

Haith, D.A., Shoenaker, L.L., 1987. Generalized watershed loading functions fo stream flow nutrients. J. Am. Water Resour. Assoc. 23, 471-478.

Han, Y., Li, X., Nan, Z., 2011. Net anthropogenic phosphorus accumulation in the Beijing metropolitan region. Ecosystems 14, 445-457.

Heathwaite, A., Fraser, A., Johnes, P., Hutchins, M., Lord, E., Butterfield, D., 2003. The Phosphorus Indicators Tool: a simple model of diffuse P loss from agricultural land to water. Soil Use Manage. 19, 1-11.

Heathwaite, A.L., Dils, R.M., 2000. Characterising phosphorus loss in surface and subsurface hydrological pathways. Sci. Total Environ. 251-252. 523-538

Jeppesen, E., 2009. Climate change effects on runoff, catchment phosphorus loading and lake ecological state, and potential adaptations. J. Environ. Qual. 38, 1930-1941.

Johnes, P.J., 1996. Evaluation and management of the impact of land use change on the nitrogen and phosphorus load delivered to surface waters: the export coefficient modelling approach. J. Hydrol. 183, 323-349.

King, R.S., Beaman, J.R., Whigham, D.F., Hines, A.H., Baker, M.E., Weller, D.E., 2004 Watershed land use is strongly linked to PCBs in white perch in Chesapeake Bay subestuaries. Environ. Sci. Technol. 38, 6546-6552.

Kleinman, P.J.A., Wolf, A.M., Sharpley, A.N., Beegle, D.B., Saporito, L.S., 2005. Survey of water-extractable phosphorus in livestock manures mention of trade names does not imply recommendation or endorsement by USDA-ARS. Soil Sci. Soc. Am. J. 69, 701-708.

Kronvang, B., Vagstad, N., Behrendt, H., Bøgestrand, J., Larsen, S.E., 2007. Phosphorus losses at the catchment scale within Europe: an overview. Soil Use Manage. 23 104-116.

Lane, S.N., Reaney, S.M., Heathwaite, A.L., 2009. Representation of landscape hydrological connectivity using a topographically driven surface flow index. Water Resour. Res. 45, 2263-2289.

Liu, B., Nearing, M., Risse, L., 1994. Slope gradient effects on soil loss for steep slopes. Trans. ASABE 37, 1835-1840.

McCool, D., Brown, L., Foster, G., Mutchler, C., Meyer, L., 1987. Revised slope steepness factor for the universal soil loss equation. Trans. ASABE 30, 1387-1396. 
Men, M., Chen, J., Yu, Z., Xu, H., 2007. Assessment of soil erosion based on SOTER in Hebei Province. Chin. Agric. Sci. Bull. 23, 587-591 (in Chinese).

Mishra, A., Kar, S., Singh, V.P., 2007. Determination of runoff and sediment yield from a small watershed in sub-humid subtropics using the HSPF model. Hydrol. Process. 21, 3035-3045.

Mittelstet, A.R., Heeren, D.M., Fox, G.A., Storm, D.E., White, M.J., Miller, R.B., 2011. Comparison of subsurface and surface runoff phosphorus transport rates in alluvial floodplains. Agric. Ecosyst. Environ. 141, 417-425.

Morse, N., Wollheim, W., 2014. Climate variability masks the impacts of land use change on nutrient export in a suburbanizing watershed. Biogeochemistry 121 , 45-59.

Nathan, R.J., McMahon, T.A., 1990. Evaluation of automated techniques for base flow and recession analyses. Water Resour. Res. 26, 1465-1473.

Natural Ecological Protection Division, S.E.P.A., 2002. National Pollution Survey on Livestock Production and Poultry Breeding and the Countermeasures. Chinese Environmental Science Press, Beijing, China (in Chinese).

Ongley, E.D., Xiaolan, Z., Tao, Y., 2010. Current status of agricultural and rural non-point source pollution assessment in China. Environ. Pollut. 158, 1159-1168.

R Development Core Team, 2012. R: A Language and Environment for Statistical Computing. R Foundation for Statistical Computing, Vienna, Austria, http:// www.R-project.org.

Renard, K.G., Foster, G.R., Weesies, G.A., McCool, D., Yoder, D., 1997. Predicting Soil Erosion by Water: A Guide to Conservation Planning with the Revised Universal Soil Loss Equation (RUSLE). Agriculture Handbook, Washington.

Sharpley, A., Kleinman, P., McDowell, R., Gitau, M., Bryant, R., 2002. Modeling phosphorus transport in agricultural watersheds: processes and possibilities. J. Soil Water Conserv. 57, 425-439.

Sharpley, A.N., Weld, J.L., Beegle, D.B., Kleinman, P.J.A., Gburek, W., Moore, P., Mullins, G., 2003. Development of phosphorus indices for nutrient management planning strategies in the United States. J. Soil Water Conserv. 58, 137-152.

Shen, Z., Liao, Q., Hong, Q., Gong, Y., 2012. An overview of research on agricultural non-point source pollution modelling in China. Sep. Purif. Technol. 84 104-111.
Shen, Z., Qiu, J., Hong, Q., Chen, L., 2014. Simulation of spatial and temporal distributions of non-point source pollution load in the Three Gorges Reservoir Region. Sci. Total Environ. 493, 138-146.

Taranu, Z., Gregory-Eaves, I., 2008. Quantifying relationships among phosphorus, agriculture, and lake depth at an inter-regional scale. Ecosystems 11, 715-725.

Turner, B.L., Leytem, A.B., 2004. Phosphorus compounds in sequential extracts of animal manures: chemical speciation and a novel fractionation procedure. Environ. Sci. Technol. 38, 6101-6108.

Vadas, P., Good, L., Moore, P., Widman, N., 2009. Estimating phosphorus loss in runoff from manure and fertilizer for a phosphorus loss quantification tool. J. Environ. Qual. 38, 1645-1653.

Williams, J., Renard, K., Dyke, P., 1983. EPIC: a new method for assessing erosion's effect on soil productivity. J. Soil Water Conserv. 38, 381-383.

Wischmeier, W.H., Smith, D.D., 1978. Predicting Rainfall Erosion Losses - A Guide to Conservation Planning, Agriculture Handbook No. 537 U.S. Department of Agriculture, Washington, DC

Withers, P.J.A., Jarvie, H.P., 2008. Delivery and cycling of phosphorus in rivers: a review. Sci. Total Environ. 400, 379-395.

Yang, Y., Chen, Y., Zhang, X., Ongley, E., Zhao, L., 2012. Methodology for agricultural and rural NPS pollution in a typical county of the North China Plain. Environ. Pollut. 168, 170-176.

Young, W.J., Marston, F.M., Davis, R.J., 1996. Nutrient exports and land use in Australian catchments. J. Environ. Manage. 47, 165-183.

Zhang, L., 2010a. Introduction of the First National Pollution Census Bulletin. Ministry of Environmental Protection, Beijing, China (in Chinese).

Zhang, T., 2010b. A spatially explicit model for estimating annual average loads of nonpoint source nutrient at the watershed scale. Environ. Model Assess. 15 569-581.

Zhou, H., Gao, C., 2011. Assessing the risk of phosphorus loss and identifying critical source areas in the Chaohu Lake Watershed, China. Environ. Manage. 48, 1033-1043.

Zhu, M., (PhD thesis) 2011. Study on Agricultural NPS Loads of Haihe Basin and Assessment on Its Environmental Impact (in Chinese). Chinese Academy of Agricultural Sciences. 